\title{
ARCHAEOLOGICAL DISCOVERIES IN JORDAN: THEIR IMPACT ON BIBLICAL STUDIES 1
}

\author{
Hannes Olivier \\ Departement Ou Testament \\ Universiteit van Stellenbosch \\ STELLENBOSCH
}

\begin{abstract}
The major impact of archaeological cxploration in Jordan on the history and development of Biblical studies is not always fully appreciated. It is shown here that several impontum innowations and developments in the field of Biblical studies are directly to be linked to stuch anchacolugicat discoveries. Morcover, contran to the more casily accessible and religiously more significant Cisjordan, cenain regions in Transjordan have remained virtually unouched until a few years ago. Consequently, they can presenly be explored by means of the most advanced suney and excavation techniques. The cument interest in the social, cultural and economical aspects of socien in Biblical times has been seried significanly by modem socio-anthropolocical based anchacological reseanch in the more isolated regions of Jordan.
\end{abstract}

\section{INTRODUCTION}

Since its inception as discipline Biblical Archaeology was intimately concerned with discoveries made in the Transjordan area. Some major incentives in its field are directly to be linked to projects that were, and still are, carried out in that territory, such as the current archaeological explorations in the Dhiban area where the famous stele of king Mesha was found by Rev. F.A. Klein in 1868 (Horn, 1983:497), and the still ongoing excavations at the Decapolis city of Jerash already discovered in 1806 by Ulrich Jasper Seetzen (Hadidi, 1986:26). It is therefore necessary to take briefly into account the relative short history of archaeological discoveries in Transjordan (Olivier, 1988:80), and subsequently to present some arguments substantiating the claim of the above-mentioned hypothesis, namely that they have important bearance on Biblical studies.

I The financial assistance of the Centre for Science Development towards the publication of this work is hereby acknowledged. Opinions expressed in this publication and conclusions arrived at, are those of the author and are not necessarily to be attributed to the Centre for Science Development. 


\section{Transjordan}

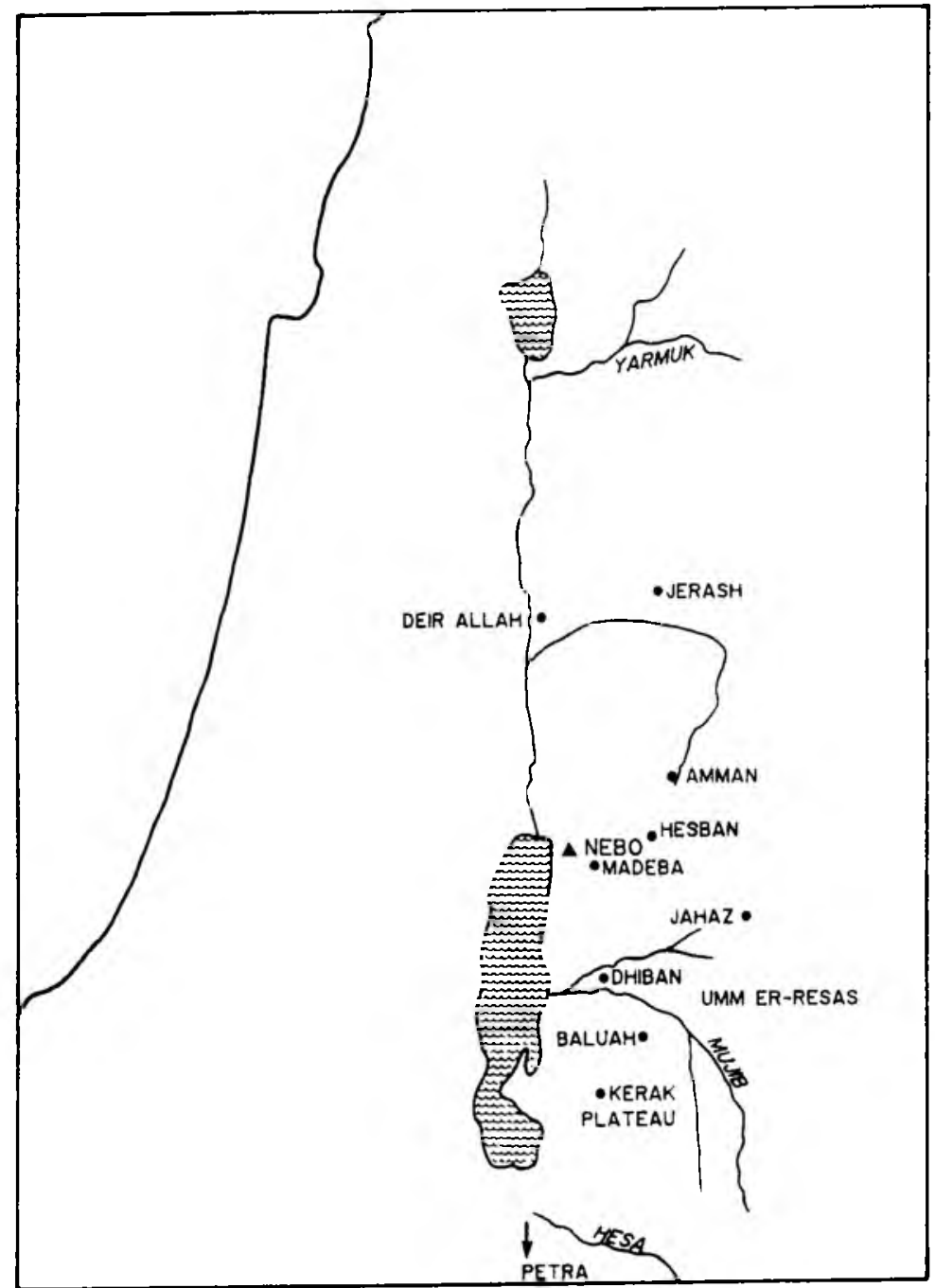




\section{TERMINOLOGY}

For the sake of conceptual clarity a few preliminary remarks are perhaps needed. The term Biblical Archaeology is only used for lack of a better one. serving to describe the specific area and period that we are interested in (Burger, 1990:4). By Transjordan is meant that part of the Hashemite Kingdom of Jordan which constitutes the habitable and relatively fertile strip of land stretching for about 220 kilometres from the Yarmuk River southwards to the el-Kerak plateau, immediately east of the Dead Sea, and beyond where it becomes very narrow indeed. The average precipitation varies considerably between the northern region and that of the southern part (Harlan, 1982:71). Altitudes also differ dramatically, e.g. from the level of the el-Lisan to Kerak (18 kilometres) the difference in altitude is 1300 metres. It is also hereby presumed that the historical continuum in its totality, that is to say. the whole complex of events and forces operative within such sphere of time and space, should be taken into account when assessing influences or something called impact. There are many salient aspects which feature in historical descriptions, but there are far more factors involved than those that have been recorded or even contemplated. So let us be modest when speaking about impact. Finally, certain inferences here depend upon the assumption that no dramatic environmental changes have taken place in the whole of this territory and its adjacent areas in the past twenty centuries or so. This would hold true of especially the isolated and rather sparsely populated el-Kerak plateau where particular modes of existence and living conditions seem to have been kept intact for many centuries until the development and resettlement programmes of the past two decades. A major advantage thereof is that the far more technologically advanced and methodologically sound archaeological research procedures could have been applied here, the results of which serve to hypothetically reconstruct the ways and means of existence in the territory of Cisjordan at any given period. These results can then be correlated with the descriptions of living conditions in the nineteenth and early twentieth-century travelogues by those daring and courageous explorers of such remote and dangerous parts of the Ottoman Empire. So let us begin with a brief historical overview.

\section{HISTORICAL OVERVIEW}

The nineteenth-century spirit of exploration which coincided with the search for unknown places and foreign cultures is nowhere better attested than in the travel reports of two students of Göttingen's famous geographer, professor Blumenthal, who both travelled, independently and in disguise, extensively in the Middle East (Olivier, 
1991:00). Seetzen's initial reports did not engender much interest for Transjordania in Europe and were, in fact, not published before 1854 . In his monthly correspondence he did. however, manage to draw sufficient attention to the well preserved Decapolis city of Jerash, the ruins of which contain splendid examples of Hellenistic, Roman and Byzantine influence in this region, and on account of which many romantically inclined explorers set foot in this region. In the wake of the Enlightenment and in concordance with the spirit of Rationalism and Naturalism travellers for a change got interested in more than mere pilgrimages to holy sites.

Jean Louis Burckhardt. on the other hand, captivated his sponsors' enthusiasm. They were British and eager to expand Britain's colonies and interests everywhere. He was, incidentally, employed by the Association for Promoting the Discovery of the Interior Parts of Africa. His discovery of Petra on August 22nd, 1812 signified extraordinary perseverance and acumen (Burckhardt, 1822:418-430). The publication of his travelogue ten years later set in motion in Europe a completely new and extremely fashionable thing to do for those who had courage and money, namely: destination Petra. In order to reach Petra the almost impenetrable territory of the hostile Majali tribe had to be crossed. Substantial payments and frequently also ransom were exacted from these notoriously naive European travellers by the sheik living at Kerak. There they also encountered Christian families who had faithfully adhered to the teachings of the Greek Orthodox Church. Unlike the situation in the Cisjordan territory the Kerak plateau was for most of the nineteenth century not under any form of control by the Sublime Porte in Istanbul. It would seem that even under such adverse circumstances the interest in Petra had never abated. Destination Petra also succeeded in furthering a general interest in all sorts of enterprises of exploratory nature within the confines of the much safer and more 'civilised' Cisjordan. Although one can literally see Kerak from Hebron, crossing the Ghor to Kerak en route to Petra was perceived an achievement comparable to reaching a destiny of immeasurable distance, only to be traversed by the most daring. Thus, instead of fostering further attempts to explore the (southern) Transjordan territory the attention and resources of the parties involved were primarily directed at the exploration of Western Palestine, the most important achievement of which was Edward Robinson's Biblical Researches of Palestine, and subsequently, the beginning of large-scale tourism to the various holy places in the Holy Land (Polkehn, 1986:70).

The famous Sihan warrior stele was the first object of real historical and artistic value to be discovered in Transjordan at Redjom el-Aabed on January 17th, 1851 (Tufnell, 1953:161; Warmenbol, 1983:63). Its discovery by the flamboyant Louis-Felicien de Saulcy caused a great deal of excitement in France and elsewhere. He claimed it to be 
a Moabite sculpture (1853:347). According to Pierre Amiet (1980:347) it reflects creativeness and vigour of superior nature in comparison to other objets d'art of the Levant. This discovery also coincided with other exhilarating discoveries in Mesopotamia and Egypt, and at the time when European powers competed against each other to acquire for their newly founded national museums as many ancient objects of art that their agents could lay their hands upon. Any such discovery as that of De Saulcy would have precipitated yet another wave of treasure hunters to the Holy Land in search for this new type of relic that could be displayed in the great and prestigious museums of Europe.

\section{THE DISCOVERY OF THE MESHA STELE}

The international relation between France, Britain and Germany became very tense indeed when one of the most famous monuments of antiquity was discovered at the Transjordanian town of Dhiban, namely the Stele of Mesha, king of the Moabites (Graham, 1989:49). The utter opportunistic and selfish way in which this unfortunate episode had been conducted by the respective governments, resulted not only in the destruction of the stele but also caused more suspicion, strife, and enmity among the local Arab tribes against further explorations of this kind (Horn, 1983:498). They were puzzled by the European's interest in these seemingly worthless stones. The only reason they could think of was that these relics contained wonderful treasures within. The reaction of the general public in London or Paris was of a completely different nature. Unsurpassed excitement in the possibilities of Biblical Archaeology was effectuated by the publication of the translation of the Mesha Stele in The Times of January 17th, 1870. "The dramatic proof of the historical accuracy of the Bible soon became popular subject of conversation in drawing rooms, dinner parties, and garden receptions throughout England," according to Silberman (1982:109). It also provided for a raison d'être in acquiring the necessary funds and public involvement for interesting parties, such as the Palestine Exploration Fund that was founded only five years earlier. For over one hundred years now the Mesha Stele has remained not only the longest but also the most important and informative document of Biblical times. It has been studied by every scholar of Biblical history, geography and toponymy; of Hebrew philology, epigraphy, lexicography and literature, and of Syro-Palestinian social anthropology and religion (Dearman, 1989:155). It is almost impossible to comprehend the full impact of the Mesha Stele on Biblical studies in general and on the history of Palestine in the ninth century B.C. in particular (Timm, 1982:157). Its subject-matter covers as diverse topics as ancient technology, road systems, fortifi- 
cations, Israelite religion, royal propaganda, international politics, etc. (Tushingham, 1990:187).

\section{THE SHAPIRA AFFAIR}

In the wake of the discovery of the Mesha Stele it is conceivable that the territory of Transjordan acquired new status among those who had deemed it their calling to find scientific proof of the reliability of the Bible, and consequently, also among fortune hunters, adventurers and missionaries. One such an opportunist was Moses Shapira, an antique dealer in Jerusalem, who had allegedly acquired in the Moabite territory what was eventually termed the 'World's Oldest Bible' (Olivier, 1988:85). The willingness of Queen Victoria to guarantee the purchase price of one million pounds sterling for these scrolls contributed considerably to the electric atmosphere of elation in London in August 1883. Unfortunately for Shapira, Clermont-Ganneau proved them to be forgeries. During the five years of the so-called Shapira affair (1878-1883) many fortune seekers visited Transjordan in search for more such original scrolls.

\section{THE DISCOVERY OF THE MADEBA MAP}

A number of pilgrims seemed to be obsessed with the idea to perceive the Holy Land from the summit of Mount Nebo as did Moses. No one succeeded, however, in discovering anything of real value. Only a few kilometers to the south-east of Mt Nebo a new church was erected at the place where a mosaic floor was discovered by a Greek monk in 1884. In January 1897 the archaeological world was stunned by the notes and sketches of father Cleopas, librarian of the Greek Patriarchate (Donner, 1965:43). They contained the invaluable information regarding the ancient mosaic floor of the Byzantine church of Madeba from about 600 A.D. (Libbey \& Hoskins, 1905:267). The mosaic floor comprised a map of the Holy Land as the Byzantine community believed Moses would have seen it. The map measured 40 feet by 60 feet $(9,6$ by $6,06 \mathrm{~m})$, and included all places of importance from the Nile Delta to Sardis in Asia Minor (and perhaps also Constantinople). Roads, natural (fauna and flora) and topographical features were artistically decorated (Keel et al., 1984:430), though its intended design was obviously to illustrate biblical history. The orientation of the map shows it to be drawn from east to west, the centre point of which was occupied by Madeba (now lost) ranking symbolically with Rome and Constantinople (Donner, 1982:174). As a major source for toponymic studies it also contains a remarkable map of Jerusalem (Bahat, 1990:76), on account of which certain excavation projects were successfully conducted 
in recent years. The sad thing about this map is that a substantial part of it was deliberately destroyed by the builder of the church of 1896 who wished to build on the exact foundations of the early church. In his address at the annual meeting of the Palestine Exploration Fund in 1899 Wilson remarked: "Even in its fragmentary state it is of the most valuable geographical discoveries of recent years in Palestine" (Wilson, 1899:316). The Madeba map is an indispensible source for reconstructing the history of Roman-Byzantine Palestine, especially the history of the early church (Canova, 1953:lxiii).

\section{EXPLORATIONS}

The discovery of the Madeba map occurred only a few years after the first attempts to survey Transjordan had failed. While the territories of the Cisjordan were already surveyed and mapped from times as early as Napoleon's unsuccessful expedition in 1799, Transjordan remained virtually untouched in this regard. The attempt sponsored by the American Palestine Exploration Society was a huge failure compared to the highly competent and efficient explorations and survey of the Sinai by British officers like Wilson, Conder and Kitchener. Conder was later appointed to survey those regions abandoned by the Americans but was stopped in 1882 by the increasingly suspicious Ottoman authorities (Olivier, 1988:84). Southern Transjordan was then a region not to traverse due to the lack of any sort of protection. The change in situation coincided with the discovery of the Madeba map when the Turkish government dispatched 2000 troops to police the Kerak district for the first time since Suleiman the Magnificent. For a brief period (1894-1905) the region was inundated by travellers who had left behind valuable records pertaining to almost anything one can think of, among them the excellent research work of Brünnow and Domaszewski (1904) and Alois Musil (1907-1908). The importance of their observations on the ways and means of existence of the local people in an environment very similar to that of Biblical times after 500 years of almost complete isolation, cannot be easily overestimated. With its emphasis on social anthropological concerns the so-called 'New' Archaeology is increasingly dependent upon this kind of information which serves as a paradigm from which certain inferences can be made.

\section{EXCAVATIONS}

With the exception of some brief soundings at Adir in 1924 by Albright and at Baluah in 1930 by Reginald Head, and some follow-up work there in 1932 solely on account of 
the discovery of the now famous Baluah Stele, the scene of Transjordan's exploration was completely dominated for the next three decades by the American archaeologist Nelson Glueck. His four volumes, Explorations in Eastern Palestine (1934-1951), "soon became, and would remain for the next half century, the standard authority on the antiquities of Moab and Edom" (Miller, 1989:146). Only in most recent years new survey projects of such extent and accuracy were again being conducted in Jordan. Glueck's work made a tremendous impact in especially the field of Biblical studies. The scarcity and almost complete absence of evidence pertaining to large-scale Middle and Late Bronze Age settlements sent many Bible historians back to the drawing board. In fact, it was largely responsible for the acceptance of the much later date of the Exodus (Mattingly, 1983:245; Miller, 1989:149). Further and more specialised research in the whole of Transjordan followed by Glueck's colleagues and students upon whom he had exerted a profound influence. Since these territories and their inhabitants are frequently being mentioned in the Bible, Biblical scholars got more and more interested in participating in and supporting excavation projects there, a prime example of which is the excavations by the Andrews University at Hesban. Glueck's surveys stimulated a new trend in the field of Biblical Archaeology, namely the emphasis on the living conditions of people within the rural regions and not so much on the monumental achievements of the urban populations. In other words, the absence of large tells in the regions of southern Jordan (Glueck, 1970:27), and the contemporary existence strategies of their inhabitants led Glueck and some of his followers to reconsider the generally accepted assumptions as to the living patterns in Biblical times. It was much more diverse. The same applies for the historical reconstructions in regard to the relationships between Israel and her neighbours on the other side of the Jordan during the so-called Biblical period (LaBianca, 1988:369). The subsequent increase in survey projects of similar nature in both the Cis- and Transjordan territories has been quite remarkable.

Apart from the abundance of material remains that testify to some particular mode of existence, the discovery of the Siran bottle inscription at the University of Jordan campus in 1972 provides for an important additional source which underscores the hypothesis of a basic agrarian life style (Smit, 1989:108). It mentions the existence of vineyards, gardens, troughs and cisterns which facilitate a joyous and happy way of living (Ahlström, 1984:14). The archaeological excavations and survey expeditions have since uncovered among the many ruins of Transjordan more and more evidence that unquestionably would substantiate this written text of 2600 years ago. The text, incidentally, also serves to reconstruct the chronology of the Ammonite kings (Herr, 1985:171). 
Of totally different nature but of the utmost importance for any study dealing with the topic of prophecy was the discovery of fragments of plaster texts at Deir Allah in the Jordan valley in 1967 . These texts which date roughly from circa 700 B.C., contain fascinating information regarding a seer named Balaam son of Beor (Hackett. 1986:220). It is undoubtedly to be related to the Biblical character Balaam. These texts also cast invaluable light on the processes of documentation in ancient times.

Of the large number of sites in Jordan that are currently being excavated that of $\mathrm{Umm}$ er-Resas is perhaps the most fascinating. The mosaic floors in the two churches provide us with new evidence of Transjordan in the Byzantine times (Piccirillo, 1988:209). The mosaics contain the names of eight cities in the Cisjordan territory, and of seven in Transjordan, among which Kastron Mefaa is most likely to be identified with and localised at Umm er-Resas. The mosaics depict specific features of the buildings and fortifications of the respective cities, their topography and surroundings. Though the relevant importance of Kastron Mefaa(t) seems to be overstated, its position on a route leading from Damascus in a southerly dirēction coincides well with the hypothesis that a whole network of roads existed in Transjordan in Roman-Byzantine times, enhancing the situation of prosperity that did exist then. The mosaics provide interesting evidence in favour of the identification of the Biblical toponyms Jahaz. Qedemoth and Mephaat (Jos. 13:18) with Jizeh(?), Saliveh and Umm er-Resas respectively. Finally, the motifs on the centre piece of the mosaics entail some highly stylised and scematic landscapes, place names and artistic representations of animals and plants, some of which reflect decidedly not a Transjordanian background, but rather that of the Nile delta. It would seem that art motifs were probably selected from a sort of catalogue for various reasons, e.g. fashion and propaganda. The mosaics of $\mathrm{L} \mathrm{mm}$ er-Resas certainly contribute to our understanding of the ecclesiastical, cultural, economical and political situation in the greater Mediterranean region at the beginning of the Christian era (De Vries, 1988:221).

\section{SURVEYS}

Presently, a substantial number of surveys are in the final process of completion. It does not lie within the scope of this paper to reiterate the names and regions of all the respective surveys that have been skilfully published by Denise Homes-Fredericq and others (Homes-Fredericq \& Hennessy, 1989). The Ain Ghazal survey by Z.A. Kafafi, the Aqaba-Main survey by W.J. Jobling, the Baq'ah valley survey by P.E. McGovern, the Wadi el-Hasa survey by B. McDonald, and especially the Kerak survey by J.M. 
Miller are among those which prove to be of considerable interest to Biblical studies; in particular to assess different modes of existence in ancient times. The results gained are based on the latest technological skills and practices, such as remote sensing, palynology, neutron activation, etc. Moreover, during the past couple of years several new large-scale archaeological projects have been initiated with specific aims. The Madeba plains project for example, is directed at reconstructing the total scenario of human occupation within that given territory (LaBianca \& Lacelle, 1986; Ihach, 1987; LaBianca, 1990). The Limes Arabicus project, on the other hand, is destined to establish all evidence pertaining to the involvement of the Roman legions between the sedentarised regions and the Great Syrian-Arabian desert in Transjordan (Parker, 1991:117).

\section{CONCLUSIONS}

It would seem that Transjordan's impressive record of archaeological discoveries has made a profound impact on Biblical studies. The Mesha Stele's contribution to the respective fields of epigraphy, lexicography and Northwest Semitic philology can never be overestimated (Drinkard, 1989:131). Equally important in this regard are discoveries such as the Deir-Allah texts and the Siran Bottle inscription. All extra-Biblical written documents are, however, mostly evaluated in terms of what light they cast in the dark corners of our ignorance. Coupled with the latest evidence on the ways of existence that were maintained in the more remote regions of Transjordan, a more balanced picture of the living conditions of people in Biblical times can be attained. The explorations, surveys and excavations in Jordan will continue to be of vital importance for historical reconstructions of all spheres of human existence and conduct (Geraty \& Willis, 1986:3). The fact that so many eminent scholars are presently engaged in so many projects related to the whole spectrum of Biblical Studies is indeed an encouraging sign.

\section{BIBLIOGRAPHY}

AHLSTRoM, G.W. 1984. The Tell Siran Bottle Inscription. PEQ, 116:12-15.

ALBRIGHT, W.F. 1924. The Archacological Results of an Expedition to Moab and the Dead Sea. $B A S O R, 14: 1-2$.

AMIET, P. 1980. The Art of the Ancient Near East. New York : H.A. Abrams.

BAHAT, D. 1990. The Illustrated Allas of Jerusalem. Jerusalem : Carta. 
BRüNNOW, R.E. \& VON DOMASZEWSKI, A. 1904. De Provincia Arabia. Auf Grund Zweier in den Jahren 1897 und 1898 unternommenen Reisen und der Berichte fruherer Reisender. Strassburg : K.J. Trubner.

BURCKHARDT, J.L. 1822. Travels in Syria and the Holy Land. London : John Murray.

BURGER, J. 1990. Biblical Archacology - a Misnomer? ThEv, 23(2):2-6.

CANOVA, R. 1954. Iscrizioni e Monumenti Protocristiani del Paese di Moab. Rome: Pontificio Istituto di Archeologia Cristiana.

DEARMAN, A. ed. 1989. Studics in the Mcsha Inscription and Moab. Atlanta : Scholars Press.

DEARMAN, A. 1989. Historical Reconstruction and the Mesha Inscription. (In Dearman, A. ed. Studies in the Mesha Inscription and Moab. Atlanta : Scholars Press. p. 155-210.)

DE SAULCY, F.L. 1853. Narrative of a Journcy Round the Dead Sea and in the Bible Lands in 1850 and 1851, edited with notes by Count Edward Warren. London: Richard Bentley.

DE VRIES, B. 1988. Jordan's Churches: Their Urban Context in Late Antiquity. BA, 51:222-237.

DONNER, H. 1965. Beobachtungen an der Mosaikkarte von Madeba. ZDPV, 81:43-46.

DONNER, H. 1982. Milleilungen zur Topographic des Ostjordanlandes anhand der Mosaikkarte von Madeba. ZDPV, 98:174-191.

DRINKARD, J.F., MATTINGLY, G.L. \& MILLER, J.A. cds. 1988. Benchmarks in Time and Culturc. An Introduction to Palcstinian Archacology. Essays in Honor of Joseph A. Callaway. Allanta : Scholars Press.

DRINKARD, J.F. 1989. The Literary Centre of the Mesha Inscription. (In Dearman: 131-154.)

GERATY, L.T. \& WILLIS, L.A. 1986. Archaeological Research in Transjordan. (In Geraty \& Herr: 3 72.)

GERATY, L.T. \& HERR, L.G. eds. 19\&6. The Archacology of Jordan and Other Studies Presented to Siegfried Horn. Berrien Springs: Andrews University Press.

GLUECK, N. 1934-1951. Explorations in Eastcrn Palestinc. I-IV ( = AASOR 14, 15, 18-19, 25-28.)

GLUECK, N. 1970. The Other Side of the Jordan. Cambridge. Ma : ASOR.

GRAHAM, M.P. 1989. The Discovery and Reconstruction of the Mesha Inscription. (In Dearman: 4192.)

HACKETT, J.A. 1986. Some Observations on the Balaam Tradition at Deir-alla. BA, 49:216-222.

HADIDI, A. 1986. Zum Stand der archacologischen Forschungen in Jordanien. (In Mittmann, S. et al. 1987. Der Königsweg. 9000 Jahrc Kunst und Kultur in Jordanien und Palastina. Mainz: Verlag Philipp von Zabern. p. 26-30.)

HARLAN, J.C. 1982. The Garden of the Lord: A Plausible Reconstruction of Nalural Resources of Southern Jordan in Early Bronze Age. Palériem, 8: 71-78.

HERR, L.G. 1985. The Servant of Baalis. BA, 4R: 169-180.

HOMES-FEDERICQ, D. \& HENNESSY, J.B. 1989. Archaeology of Jordan. Field reports. 2 Vols (= Akkadica VII \& VIII) Leuven : Peters.

HORN, S. 1983. The Discovery of the Moabite Stone. (In Meyers, G.L. \& O'Connor, M. eds. The Word of the Lord Shall Go Forth. Essays in Honor of David Noel Freedman in Celebration of his Sixtieth Birthday. Philadelphia : Eisenbrauns. p. 497-505.)

IBACH, R. 1987. Archaeological Survey of the Hesban Region. Catalogue of Siles and Characterization of Periods. (= Hesban 5). Berrien Springs : Andrews University Press .

KEEL, O., KUECHLER, M \& UEHLINGER, C. 1984. Orte und Landschaften der Bibel. Ein Handbuch und Studien-Reisefucrer zum Heilige Land. Band I. Zürich/Göttingen : Benziger/Vandenhoeck \& Ruprecth

LABIANCA, O. 1988. Sociocultural Anthropology and Syro-Palestinian Archacology. (In Drinkard $e t$ al. :369-388.)

LABIANCA, O. 1990). Sedentarization and Normadization: Food System Cycles at Hesban and Vicinity in Transjordan (=Hesban 1). Berrien Springs : Andrews Universily Press. 
LABIANCA, O. \& LACELLE, L. 1980. Environmental Foundations. Studics of Climatical. (ieological, Hydrological, and Phytological Conditions in Hesban and Vicinity (= Heshan 2). Bcrricn Springs : Andrews Universily Press.

LIBBEY, W. \& HOSKINS, F.E. 1905. The Jordan Valley and Petra. New York/London : (j.P. Putnam's Sons.

MATTINGLY, G.L. 1983. The Exodus Conquest and the Archacology of Transjordan: N'u Light on an Old Problem. Grace Theological Joumial, 42:245-262.

MILLER, J.M. 1989. Recent Archacological Exploration on the El-Kerak Plateau. JNSL X1 : 143-154

MUSIL. A. 1907-08. Arahia Petraca. Vienna: Alfred Holder.

OLIVIER, H. 1988. Nineteenth Century Travelogues and the Land of Moab ( $/ h$ Sharon, $M$ ed. Pillars of Smoke and Fire. The Holy Land in History and Thought. Johannesburg : Southern. p. 80-95.)

OLIVIER, H. 1991. The Dawn of Biblical Archaeology. JNSL, XVI:00.

PARKER, S. 1991. Preliminary Report on the 1989 Season of the Limes Arabicus Projecl. BASOR, Suppl. 27:117-143.

PICCIRILLO, M. 1988. The Mosaics at Um cr-Rasas in Jordan. BA, 51:208-214.

POLKEHN. K. 1986. Palastina. Reisen im 18. und 19. Berlin : Verlag der Nation.

SMIT. E.J. 1989. The Tell Siran Inscription. Linguistic and Historical Implications. JSem, 1(1):1108-117.

SILBERMAN, N.A. 1982. Digging for (iod and Country. Exploration. Archacology, and the Secret Struggle for the Holy Land, 17\%9-1917. New York: Alfred Knopf.

TIMM, S. 1982. Die Dynastie Omri. Qucllen und Untersuchungen zur Geschichte lsracls im 9. Jahrhundert vor Christus. Gottingen : Vandenhexeck \& Ruprecht.

TUFNELL, O. 1953. The Shihan Warrior. Iraq, 15: 161-166.

TUSHINGHAM, A.D. 1990. Dhiban Reconsidered: King Mesha and his Works. $A D A J, 34: 183-191$.

WARMENBOL, E. 1983. La Stele de Rugm El-Abd (Louvte AO 5055), Une Image de Divinite Moabilc du IXeme-VIIIeme Siecle av N.E. Levani, 15:63-75.

WILSON, C.W. 1899. Address Delivered at the Annual Mecting of the Fund. PEFQS, :304-316. 